\title{
Influence of low concentrations of cadmium, copper and zinc on phytoplankton of natural water samples
}

\author{
K. Wolter ${ }^{1}$, U. Rabsch ${ }^{1}$, P. Krischker ${ }^{1}$ and A. G. Davies ${ }^{2}$ \\ ${ }^{1}$ Institut für Meereskunde an der Universität Kiel, Düsternbrooker Weg 20, D-2300 Kiel, Federal Republic of Germany \\ ${ }^{2}$ Marine Biological Association, Citadel Hill, Plymouth PL1 2PB, England
}

\begin{abstract}
Water samples from different areas were investigated after addition of varying concentrations of heavy metals $(\mathrm{Zn}, \mathrm{Cd}, \mathrm{Cu})$. Accumulation of metal by phytoplankton was measured, employing the radio isotopes $\mathrm{Cd}-109, \mathrm{Zn}-65$ and $\mathrm{Cu}-64$. Influence of metal to carbon fixation rate of phytoplankton and to glucose incorporation by bacteria was determined. Accumulation of metal, expressed as enrichment factor, was highest at the lowest ambient metal concentration. At higher concentrations a constant value was reached. This change in enrichment was related to plankton activity. Corresponding data of metal content per chlorophyll $a$ unit for the point when accumulation changes are compared for different samples. It is discussed that these concentrations vary for different organisms.
\end{abstract}

\section{INTRODUCTION}

Although some heavy metals, such as $\mathrm{Zn}$ and $\mathrm{Cu}$, are essential for enzymatic activities, heavy metals may negatively affect life at concentrations higher than physiologically necessary. As Davies (1978) concluded in his review, the scientific interest in metal toxicity is moving away from considerations of lethal conditions towards sublethal effects, resulting from long-term exposure to low but supra-normal levels. Metal accumulation by plankton organisms over many orders of magnitude in culture experiments has been shown, e.g. by Rabsch et al. (1984). Above certain metal levels, photosynthetic processes in plankton may decrease (Davies and Sleep, 1979). A second aspect of metal accumulation by plankton is the transport of metal into food chains with possible further increase (bioaccumulation).

The metal content of organisms depends on concentrations in the ambient water as well as on metal bioavailability (Davies, 1978; Canterford and Canterford, 1980; Rai et al., 1981). Determinations in water should distinguish between different chemical forms. Fisher and Frood (1980) concluded that metal, added to DOC-rich water, had a lesser effect on phytoplankton than in low-DOC water. Since algae take up metals mainly in the ionic form (Canterford and Canterford,
1980), even low concentrations of metals, depending on their availability, can affect organisms severely. Experiments with the phytoplankter Prorocentrum micans (Rabsch et al., 1984) in water with low DOC showed that $\mathrm{Cd}$ was strongly concentrated by the cells at low concentrations in low-DOC water, affecting the development of the population concerned. For $\mathrm{Zn}, \mathrm{Cd}$ and $\mathrm{Cu}$, added to the water in ionic form, we have tested availability and uptake in phytoplankton populations in Kiel Fjord, North Sea, and a coastal area of the North Atlantic Ocean. Enrichment factors at different concentrations were calculated. Additionally, the influence of metal on carbon fixation rate was measured.

\section{MATERIAL AND METHODS}

Water samples were taken in 20 to $30 \mathrm{l}$ 'Duran' glass bottles using a peristaltic pump with silicon tubing for pumping, and teflon tubing for conveying. Subsamples were then filled into $1 \mathrm{l}$ quartz bottles. All bottles were washed with 'nitrose' gases to remove organic films and adsorbed metals from the glass walls, and tubes were washed with nitric acid. Different concentrations of $\mathrm{Zn}, \mathrm{Cd}$ or $\mathrm{Cu}$ were added to the subsamples as diluted Merck-Titrisol $\mathrm{Cl}^{-}$standards. Additionally, carrierfree $\mathrm{Zn}-65$ and Cd-109 were added as radioac- 
tive tracer isotopes. These tracers were used in all experiments, regardless of the metal added. All subsamples were equilibrated for $24 \mathrm{~h}$ (Davies and Sleep, 1979); one control, without addition of metal, was included. To determine carbon fixation rates $3 \times 50 \mathrm{ml}$ subsamples were incubated after addition of $74 \mathrm{kBq}$ 14-C-carbondioxide for $4 \mathrm{~h}$ in 'Sovirell' flasks. These samples were filtered through 2 superimposed $0.45 \mu \mathrm{m}$ Sartorius membrane filters. Contents of $\mathrm{Cd}$ and $\mathrm{Zn}$ were measured by radioactivity, and carbon fixation rate was calculated as described by Rabsch et al. (1984).

For Zn-65 and Cd-109 measurements, further $50 \mathrm{ml}$ samples of each 11 subsample were filtered after incubation through 2 superimposed $0.45 \mu \mathrm{m}$ Sartorius membrane filters. Measurements and calculations were done according to Rabsch and Elbrächter (1980). Metal uptake by the organisms is expressed as enrichment factor (EF):

$$
E F=\frac{\text { Metal in Plankton }}{\text { Plankton volume }} \times \frac{\text { Water volume }}{\text { Metal in water }}
$$

Metal content of plankton was calculated assuming isotope equilibrium with the metal already present in solution. This is probably not the case for Zn (Bernhard and Zattera, 1969; Branica, 1970; Duinker and Kramer, 1977). However, the added $\mathrm{Zn}$ and $\mathrm{Zn}-65$ were in the same form and their concentrations were much larger than those present in the water before addition. Since the amounts taken up are larger than those present before in the plankton, the EF expression remains valid, except in experiments where no stable $\mathrm{Zn}_{n}$ was added.

Bacterial activity was measured in time-series experiments. Several $10 \mathrm{ml}$ subsamples were incubated with $925 \mathrm{~Bq} 14$-C-glucose $\left(0.02 \mu \mathrm{g} \mathrm{Cl}^{-1}\right)$ and fixed with formaldehyde after short-time intervals. Samples were filtered through $0.2 \mu \mathrm{m}$ Sartorius membrane filters; radioactivity was measured and calculated as counts per minute of incorporated glucose. Phytoplankton was counted in fixed samples (Lugol's solution) with an inverted microscope. Size of cells was measured and carbon content was calculated after Smetacek (1975). Chlorophyll was measured according to UNESCO (1966). Metal concentration in water were measured by flameless atomic absorption spectrometry after Kremling and Petersen (1981).

Investigations in Kiel Fjord. During spring and autumn plankton bloom, 13 surface samples were taken in Kiel Fjord. Metals were added to subsamples to give concentrations in the range 4.3 to $304.3 \mu \mathrm{g}$ $\mathrm{Zn}^{-1}, 0.08$ to $20.08 \mu \mathrm{g} \mathrm{Cd} \mathrm{l}^{-1}$, and 0.1 to $21.5 \mu \mathrm{g}$ $\mathrm{Cu} 1^{-1}$. In 2 experiments $\mathrm{Cu}-64$ was also used. Activity of Cu-64 was determined as difference between 2 measurements in a liquid scintillation counter. The second measurement was done after $\mathrm{Cu}-64$ decay. Carbon fixation rates in water samples were determined before and after metal equilibration. For equilibration and incubation an Infors-Incubator was used with an illumination of $115 \mu \mathrm{E}\left(\mathrm{m}^{2} \mathrm{~s}\right)^{-1}$, a light/dark cycle of $12: 12 \mathrm{~h}$, and a close-to-in situ temperature.

Investigation of samples during $R V$ Poseidon cruise. During a cruise with RV Poseidon in 1981 surface water samples ('Poseidon' samples) of 13 stations situated in the North Sea, English Channel, Gulf of Biscaya and North Atlantic Ocean (coastal water off Portugal) were investigated as described above. Additionally, subsamples were incubated immediately after addition of metals, with C-14-glucose to measure bacterial activity, and with $14-\mathrm{CO}_{2}$ to measure carbon fixation by phytoplankton. Incubation of all samples during the cruise was done under natural light conditions. The added metal concentrations were lower than in the Kiel Fjord experiments. They ranged between 0.29 to $1.45 \mu \mathrm{g} \mathrm{Zn}^{-1}, 0.50$ to $2.50 \mu \mathrm{g} \mathrm{Cd} \mathrm{l}^{-1}$, and 0.28 to $1.41 \mu \mathrm{g} \mathrm{Cu} \mathrm{l}^{-1}$.

\section{RESULTS}

\section{Investigations in Kiel Fjord}

Fig. 1 to 3 show results obtained in Kiel Fjord. The carbon fixation capacity of the plankton is presented as percentage of the control (Fig. 1a, 2a, 3a). Fig. 1b, 2b, $3 \mathrm{~b}$ and $3 \mathrm{c}$ illustrate the EF of the isotopes of $\mathrm{Zn}$ and/or $\mathrm{Cd}$, present as tracer in each experiment. The EF's are highest at the lowest added concentrations of $\mathrm{Zn}$ and $\mathrm{Cd}$ (Fig. 1c, 2c). For $\mathrm{Cu}$ (Fig. 3d) there might be a similar though less clear trend. EF's for $\mathrm{Cu}$ and $\mathrm{Zn}$ reach almost values of $10^{5}$; for $\mathrm{Cd}$ the value is one order of magnitude smaller. With increasing metal concentration EF values decrease to more or less constant levels in the range we investigated. Constant EF values imply that concentrations in plankton increase proportionally to metal concentration in water. The EF's of the tracer concentrations of $\mathrm{Zn}$ and $\mathrm{Cd}$ should be constant because of the constant concentrations in the water of subsamples. The plots suggest that $\mathrm{Cd}$ is replaced by $\mathrm{Zn}$ at increasing $\mathrm{Zn}$ concentrations (Fig. 1b) and that both $\mathrm{Zn}$ and $\mathrm{Cd}$ are replaced by $\mathrm{Cu}$ at increasing $\mathrm{Cu}$ concentrations (Fig. 3b, c)

Correspondence between percentage carbon fixation and EF is observed for $\mathrm{Cd}$ and $\mathrm{Cu}$. As the standard variation of the method was $7 \%$ (Rabsch et al., 1984), we consider a change of at least $10 \%$ in the carbon fixation rate as evidence for damage. At $\mathrm{Cu}$ and $\mathrm{Cd}$ concentrations above which the EF remains constant, the reduction exceeds $10 \%$. This trend is not clear for $\mathrm{Zn}$, possibly as result of a less toxic effect of $\mathrm{Zn}^{2+}$. $\mathrm{Zn}$ reduces plankton activity only at concentrations above 

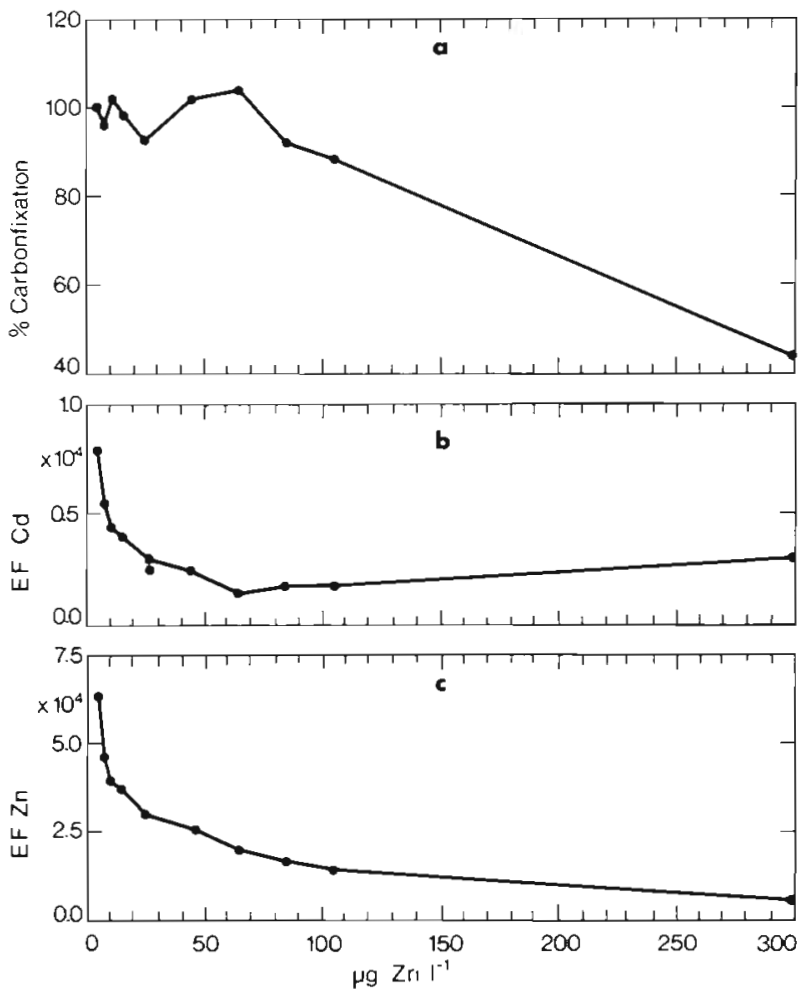

Fig. 1 a-c. Carbon fixation rate as percentage of control (a), and enrichment factors $(E F)(b, c)$, in relation to added concentrations of $\mathrm{Zn}$ to water of Kiel Fjord
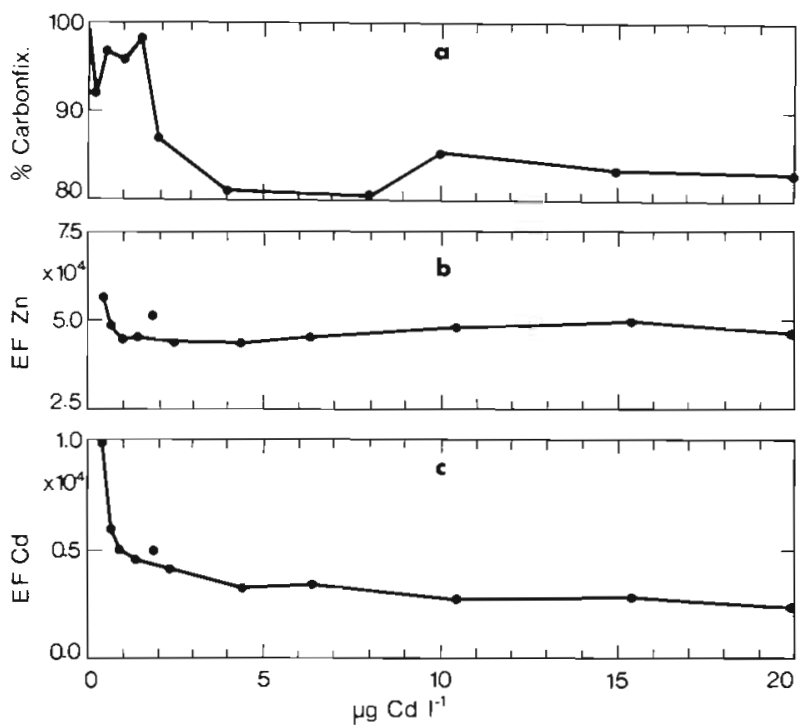

Fig. 2 a-c. Carbon fixation rate as percentage of control (a), and enrichment factors (EF) (b, c), in relation to added concentrations of $\mathrm{Cd}$ to water of Kiel Fjord

$100 \mu \mathrm{g} \mathrm{l}^{-1}$. Cd affects carbon fixation rate at a lower concentration than do $\mathrm{Cu}$ and $\mathrm{Zn}$.

Bacteria from Kiel Fjord are more sensitive in their reaction in the presence of $\mathrm{Zn}$. Fig. 4 shows the decrease of bacterial glucose incorporation with
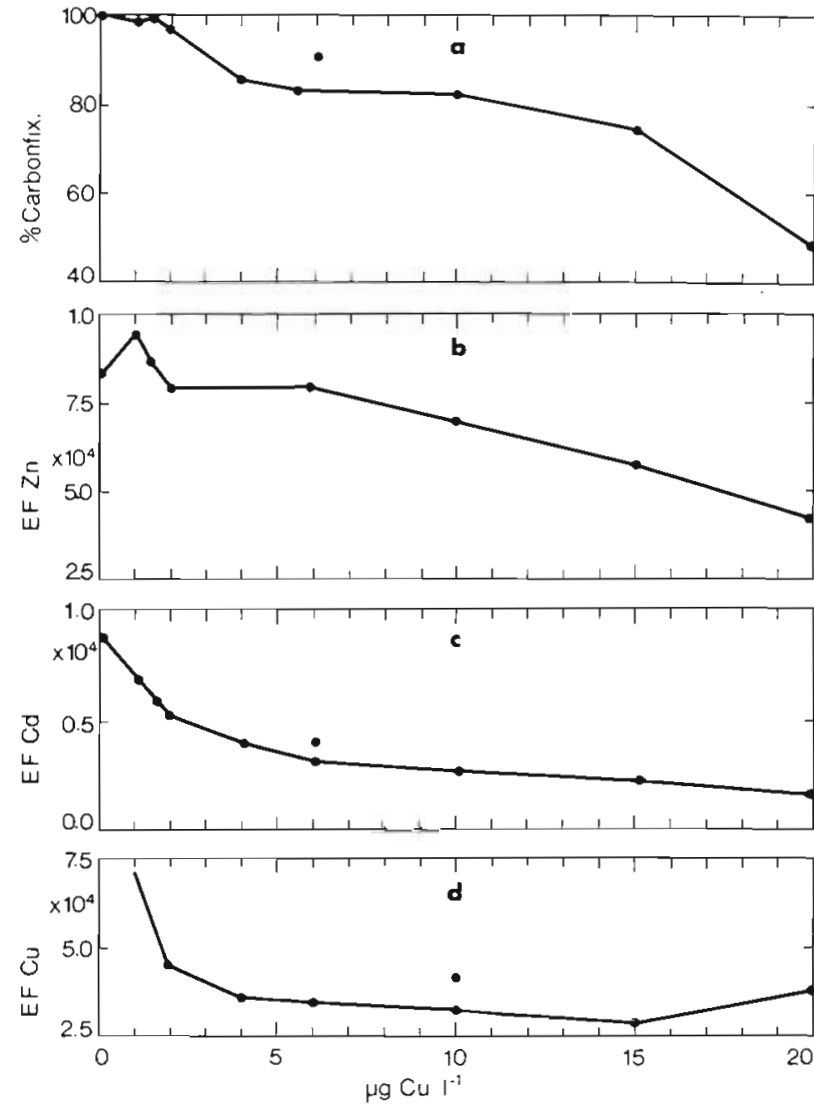

Fig. 3 a-d. Carbon fixation rate as percentage of control (a), and enrichment factors (EF) (b, c, d), in relation to added $\mathrm{Cu}$ concentrations to water of Kiel Fjord

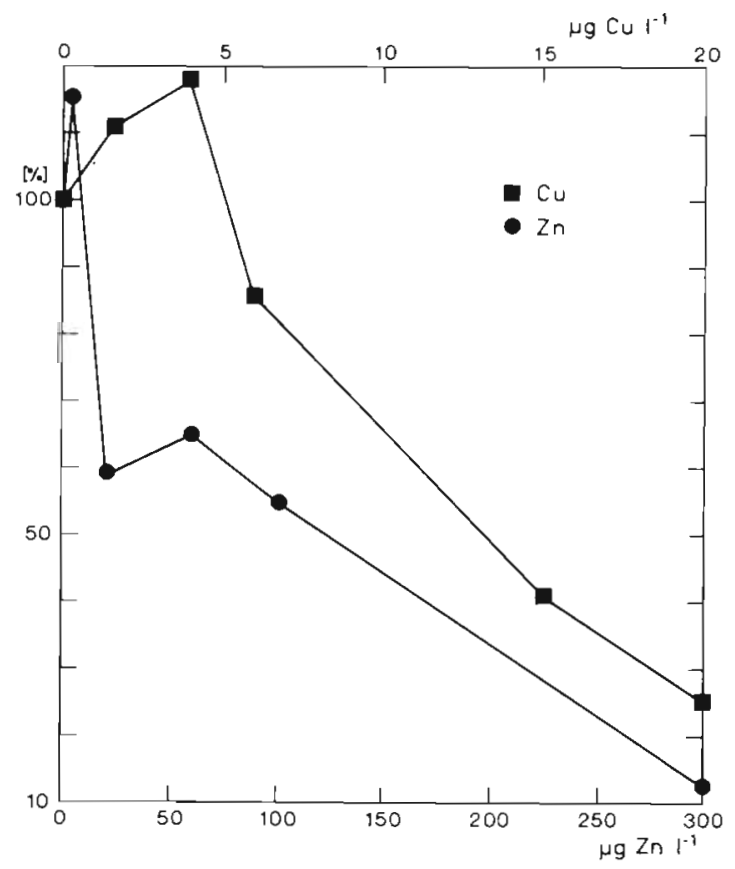

Fig. 4. Incorporation of radioactive glucose by bacteria as percentage of a control in relation to increasing concentrations of $\mathrm{Zn}$ and $\mathrm{Cu}$ in water of Kiel Fjord 
increasing $\mathrm{Cu}$ and $\mathrm{Zn}$ concentrations. At low concentrations of both $\mathrm{Cu}$ and $\mathrm{Zn}$, bacterial activity increased; it drastically decreased at $20 \mu \mathrm{g} \mathrm{Zn}$ and $6 \mu \mathrm{g} \mathrm{Cu}{ }^{-1}$. Glucose incorporation at low metal concentrations exceeds $100 \%$. We have observed similar effects for the carbon fixation capacity of plankton in several experiments.

\section{Investigations of 'Poseidon' samples}

The added metal concentrations employed during the 'Poseidon' cruise were below those in Kiel Fjord samples due to the lower concentrations in the water compared to Baltic Sea water. Accumulation of $\mathrm{Zn}$ and $\mathrm{Cd}$, expressed as EF, is presented in Fig. 5. The curves are based on different experiments. Only at 1 station is the accumulation more than proportional at the lowest concentration $(5,1)$. The 4 other experiments yielded relatively constant EF values with increasing metal concentrations in the water. Accumulation of metal was, therefore, proportional to its concentration in the water. Carbon fixation measurements, carried out $4 \mathrm{~h}$

\section{EF Zn}

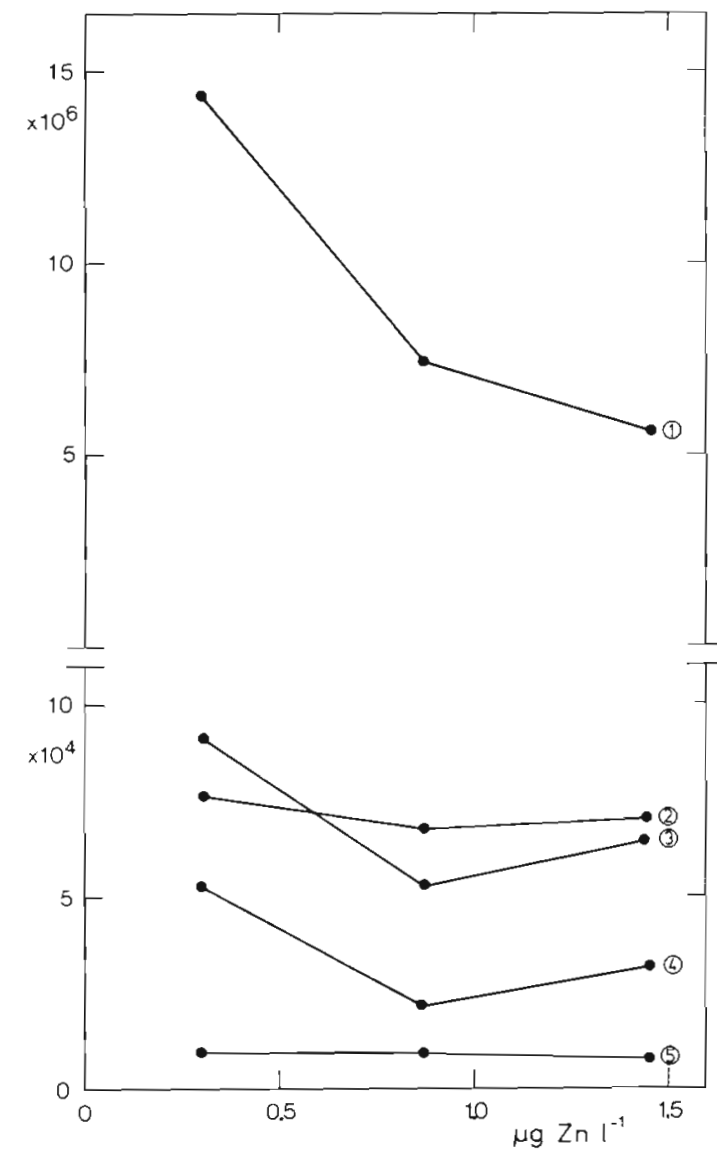

and 24 h after metal addition, did not reveal a decrease of plankton activity. The same was true for bacterial glucose incorporation in the presence of $\mathrm{Zn}$ and $\mathrm{Cd}$. $\mathrm{Cu}$, however, reduced bacterial activity drastically after $24 \mathrm{~h}$ incubation (Fig. 6b). Time results of radioactive glucose incorporation (expressed as counts $\min ^{-1}$ ) are presented for the experiment started directly after the $\mathrm{Cu}$ addition (Fig. 6a) and after a $24 \mathrm{~h}$ incubation with $\mathrm{Cu}$ (Fig. 6b).

The observation for Kiel Fjord that metal accumulation in plankton varies with metal concentration in water contrasts with the findings for samples of the 'Poseidon' cruise. The relations between population density, EF and concentrations of Cd are illustrated in Fig. 7. This graph also contains some data from culture experiments with the dinoflagellate Prorocentrum micans (Rabsch et al., 1984). A relation exists between biovolume, $\mathrm{Cd}$ concentration in water and EF. Irrespective of the sample, the lower the biovolume and the added Cd concentration, the higher the EF. For this comparison one should keep in mind that EF is dimensionless. Hence, EF's obtained for the same Cd concentration can be compared. The highest EF was found

\section{EF Cd}

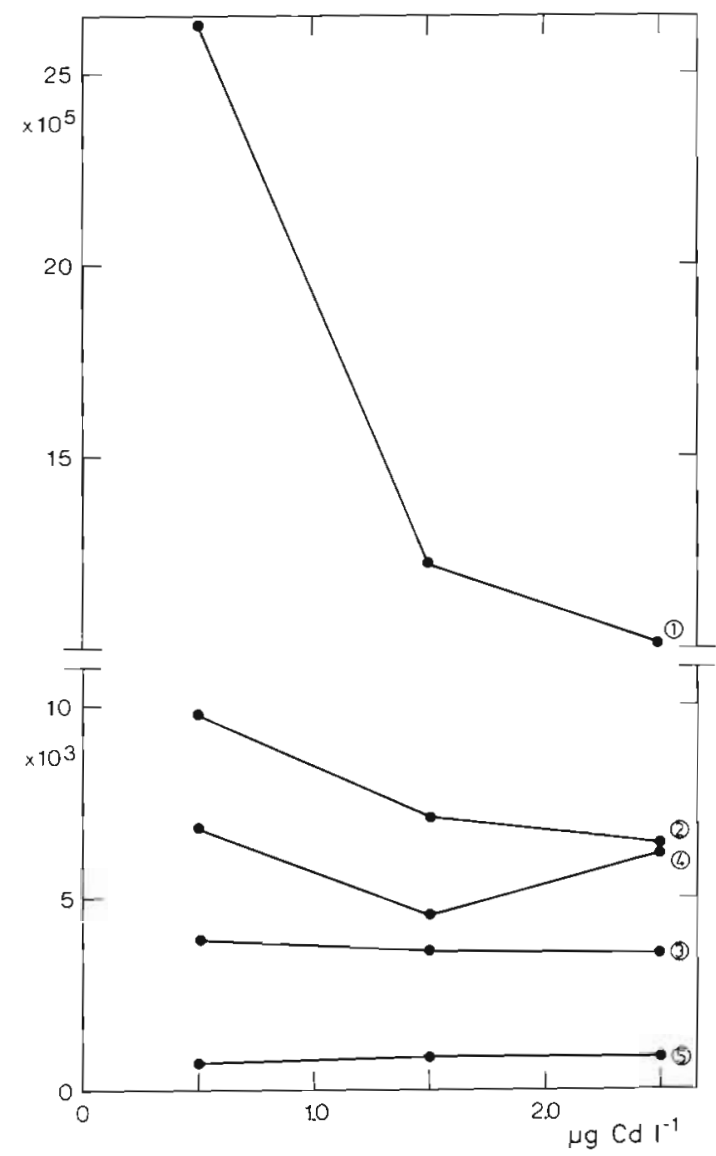

Fig. 5. Enrichment factors of $\mathrm{Zn}$ and $\mathrm{Cd}$ at increasing concentrations in water of 'Poseidon' samples. Encircled numbers: corresponding water samples 


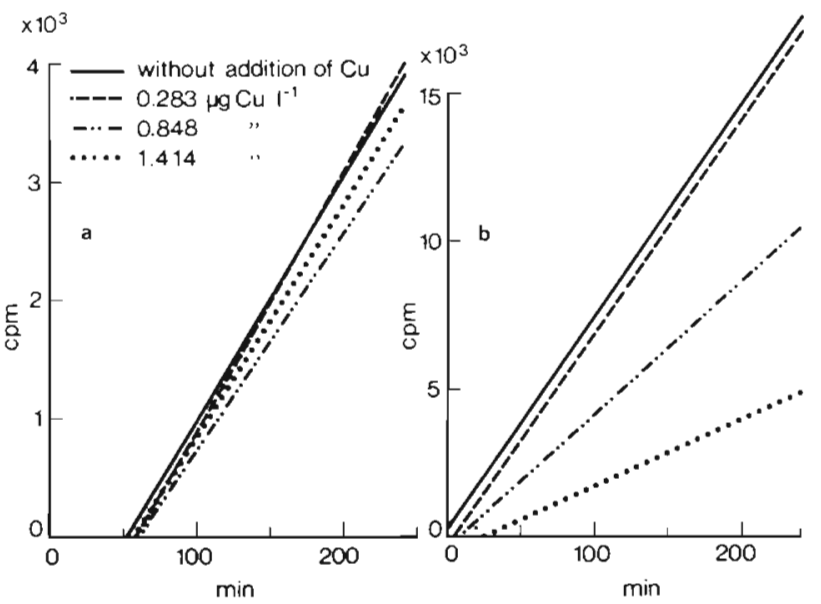

Fig. 6. Time-course experiments of bacterial incorporation of radioactive glucose at different concentrations of $\mathrm{Cu}$ in water of 'Poseidon' samples; (a) directly after addition of $\mathrm{Cu}_{\text {; }}$ (b) after $24 \mathrm{~h}$ equilibration with $\mathrm{Cu}$

in a sample of the 'Poseidon' cruise which contained mainly small flagellates. The next highest EF's were obtained during culture experiments with a dinoflagellate and relatively low DOC-concentrations. All other samples from 'Poseidon' cruise as well as from Kiel Fjord were water samples with mixed phytoplankton populations which were dominated by diatoms. The EF's in these samples were almost equal over a wide range of biovolume. Only in the sample with the highest biovolume the EF drops. This sample contained mainly large diatoms belonging to the genus Rhizosolenia.

\section{DISCUSSION}

Our results show that metal accumulation by the phytoplankton examined is higher at low Cd concentrations and that EF values are related to biovolume concentration in water. In most cases, accumulation was accompanied by a measureable loss in phytoplankton activity. Higher accumulation at the lowest added concentration of Cd was also found by Kayser and Sperling (1980) in culture experiments with Prorocentrum micans. They interpreted this observation in terms of ion-exchange behavior of Cd. Decreasing EF values with increasing metal concentration in water were also reported for heavy metals other than $\mathrm{Cd}$ (Canterford et al., 1978). In an earlier study we found that the accumulation in the cells increased proportionally at Cd concentrations above $10 \mu \mathrm{g}$, so that EFvalues were constant (Rabsch et al., 1984). No saturation was reached at concentrations up to $50 \mu \mathrm{g} \mathrm{l}^{-1}$. EF values were higher at concentrations below $10 \mu \mathrm{gl}^{-1}$. We showed that this was due to the metabolism of the organisms tested. Cells were affected at higher $\mathrm{Cd}$ concentrations so that their activity decreased and active accumulation of $\mathrm{Cd}$ stopped. Further uptake of $\mathrm{Cd}$ at higher concentrations was due to passive accumulation. This is also true for the data presented here. Results from experiments with Kiel-Fjord samples and added $\mathrm{Cd}$ show that the EF of $\mathrm{Cd}$ (Fig. 2) decreased up to concentrations of $4 \mu \mathrm{g} \mathrm{l}^{-1}$ and remained constant at concentrations up to $20 \mu \mathrm{g} \mathrm{l}^{-1}$. This constant value shows that accumulation is proportional to concentration; it therefore seems to be diffusion controlled. Hence, the higher EF below $4 \mu \mathrm{gl}^{-1} \mathrm{Cd}$ must be due to an additional mechanism which we

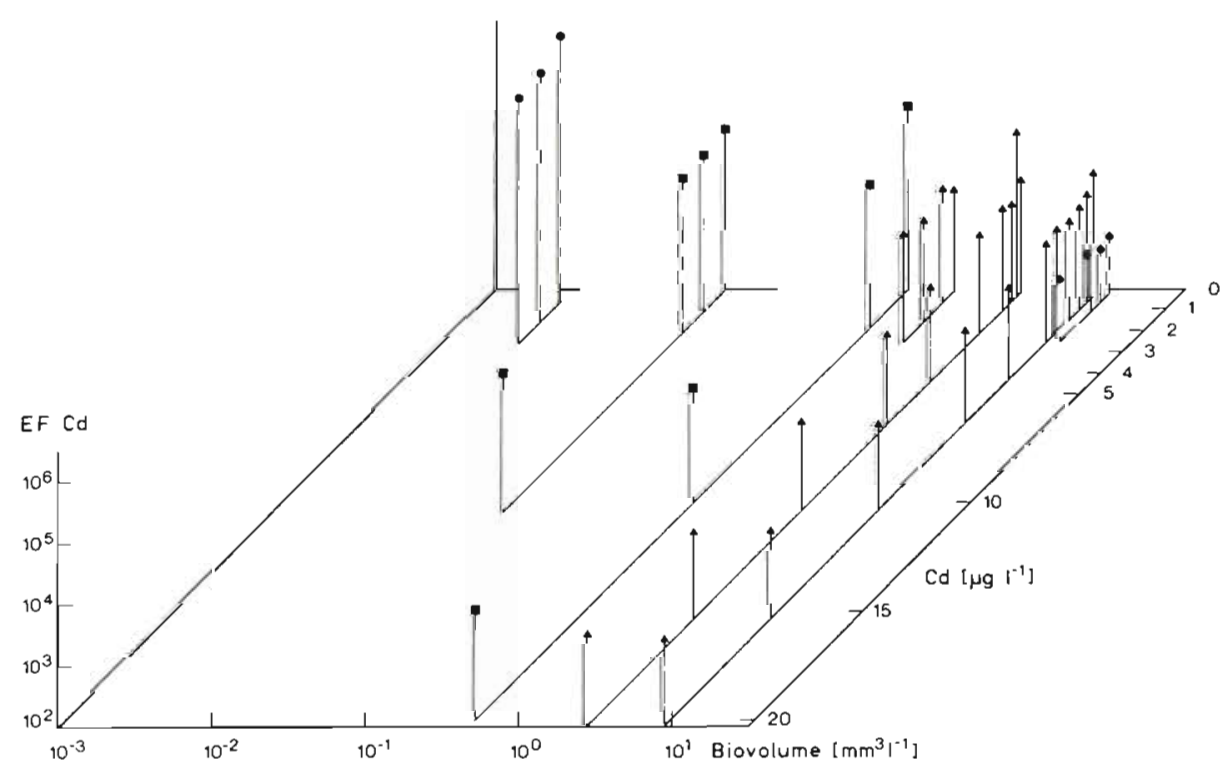

Fig. 7. Relation between enrichment factor (EF) of $\mathrm{Cd}$ at different Cd-concentrations added to water with different biovolume. Cultivation experiments with dinoflagellate Prorocentrum micans ${ }^{-}$; sample obtained during 'Poseidon' cruise containing mainly small flagellates $\bullet$; samples from Kiel Fjord and Poseidon cruise containing mixed populations of diatoms $\boldsymbol{\Lambda}_{i}$ 'Poseidon' sample containing mainly large diatoms of Rhizosolenia sp. 
interpreted as accumulation by acitve uptake. From data of 9 further experiments with Kiel-Fjord samples and $\mathrm{Cd}$ additions we know that $4 \mu \mathrm{g} \mathrm{l}^{-1}$ is not a threshold concentration. In other experiments we also found a limiting value, but this changed in the broad

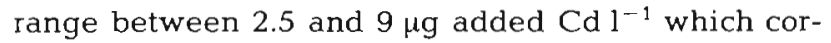
responded to a range of 2 to $23 \mathrm{ng} \mathrm{Cd}(\mu \mathrm{g} \mathrm{Chl} \mathrm{a)})^{-1}$ as extreme values. The majority of the experiments gave values between 2 and $7 \mathrm{ng} \mathrm{Cd}(\mu \mathrm{g} \mathrm{Chl} \mathrm{a})^{-1}$. Data of the different experiments are not directly comparable because the investigations were carried out at different time of the year and with different plankton populations.

According to Davies and Sleep $(1979,1980)$ for natural water samples there exists a correlation between metal content per chlorophyll $a$ and carbon fixation rate. They found that $\mathrm{Cu}$ and $\mathrm{Zn}$ concentration per cell approached a saturation value and the carbon fixation rate decreased until this saturation was reached, and then gradually leveled off at higher concentrations. They refer to hypothetical values of $1.39 \mu \mathrm{g} \mathrm{Zn}\left(\mu \mathrm{g} \mathrm{Chl} \mathrm{a)^{-1 }}\right.$ and $0.28 \mu \mathrm{g} \mathrm{Cu}(\mu \mathrm{g} \mathrm{Chl} \mathrm{a)})^{-1}$ at which photosynthesis would cease completely. From their figures it appears that carbon fixation rates start to decrease from $0.2 \mu \mathrm{g} \mathrm{nn}(\mu \mathrm{g} \mathrm{Chl} \mathrm{a)})^{-1}$ and $0.1 \mu \mathrm{g} \mathrm{Cu}$ $(\mu \mathrm{g} \mathrm{Chl} \mathrm{a})^{-1}$ onwards. In Kiel Fjord we have found a similar reduction of carbon fixation at 0.1 to $0.2 \mu \mathrm{g} \mathrm{Cu}$ $(\mu \mathrm{g} \mathrm{Chl} \mathrm{a})^{-1}$. Cu exerts a drastic effect. Fisher and Frood (1980) showed that $\mathrm{Cu}$ was the most, $\mathrm{Cd}$ the least, toxic metal. For $\mathrm{Zn}$ we found a strong carbonfixation decrease only at the highest added concentration. The corresponding value $-1.32 \mu \mathrm{g} \mathrm{Zn}(\mu \mathrm{g}$ $\mathrm{Chl} \mathrm{a)^{-1 }}$ - is close to the hypothetical value calculated by Davies and Sleep. For the concentration at which carbon fixation starts to decrease we found a value of $0.1 \mu \mathrm{g} \mathrm{Zn}(\mu \mathrm{g} \mathrm{Chl} \mathrm{a})^{-1}$ in 'Poseidon' samples. This is below the value reported by Davies and Sleep (1979). Although $\mathrm{Cd}$ was concentrated 2 orders of magnitude less than $\mathrm{Cu}$ or $\mathrm{Zn}$, expressed per unit chlorophyll $a_{\text {, it }}$ nevertheless affected the activity of phytoplankton. Especially the correspondence of carbon-fixation reduction and reduced EF (Fig. 2) underlines that stronger $\mathrm{Cd}$ accumulation at the low added Cd concentration is related to active cells and possibly to active metal uptake by the organisms. Cd accumulation hardly changed in 4 of the 5 experiments carried out with the 'Poseidon' samples; correspondingly, no reduction of carbon fixation was observed. Possibly, the critical $\mathrm{Cd}$ concentration was not reached. The values were below $3 \mathrm{ng} \mathrm{Cd}(\mu \mathrm{g} \mathrm{Chl} \mathrm{a})^{-1}$. The one sample in which a change in accumulation occurred (Fig. 5,1 ) had a higher Cd content per chlorophyll $a_{\text {, }}$ $12 \mathrm{ng}(\mu \mathrm{g} \mathrm{Chl} \mathrm{a})^{-1}$. The fact that no change in carbon fixation rate was manifest in this experiment indicates that the change of metal accumulation might be a more sensitive criterion for detecting metal concentrations harmful to organisms.

In the culture experiments mentioned above we also did not find a clear reduction of carbon fixation in Prorocentrum micans. Nevertheless, the toxic influence of Cd could be demonstrated at the population level when the growth of the population was observed long enough. Therefore, there are different criteria for assessing the degree of inhibition of organisms caused due to excessive metal concentrations: (1) Change in active metal uptake by the cells. This can be illustrated either as a change in slope of the relation between metal per cell or chlorophyll $a$ and metal concentration in water, or as sharp decrease of EF with increasing metal concentrations. (2) Decrease in metabolic activity. This can be demonstrated in measuring carbon fixation for example. Both (1) and (2) reflect the response of single cells. (3) Change in the development of the whole population. Different growth of the whole population can be detected in following the growth curve as it was shown in Rabsch et al. (1984) for a dinoflagellate culture.

Regarding the first criterion we found a change in $\mathrm{Cd}$ accumulation with increasing $\mathrm{Cd}$ concentration in water in the sample with flagellates, but no change in accumulation in the sample with Rhizosolenia sp. (Fig. 7). Rhizosolenia sp. had concentrated $\mathrm{Cd}$ to $\mathrm{a}$ lesser degree and seems therefore not to be affected by the added concentrations. One would like to explain this by the higher biovolume and hence lesser availability of the metal ion in this sample but this should also be true for the sample with the second highest biovolume (ca. $9 \mathrm{~mm}^{3} \mathrm{l}^{-1}$; Fig. 7). Here we found higher EF and also a change in accumulation which was related to $5 \mathrm{ng} \mathrm{Cd}(\mu \mathrm{g} \mathrm{Chl} a)^{-1}$. We therefore assume that the difference is due to the different organisms involved. Comparing the small biovolume of the flagellate sample with the larger one of the Rhizosolenia sp. sample an enormous number of single cells of flagellates and a relatively small number of large diatoms are involved, respectively. Fig. 7 reveals that the flagellates and dinoflagellates can accumulate a higher amount of $\mathrm{Cd}$ before change in accumulation occurred, whereas in 2 out of 3 graphs of mixed populations accumulation change occurs at lower enrichment factors (and also lower concentration per chlorophyll a). Hence, differential sensitivity of the organisms to $\mathrm{Cd}$ might be responsible. Similar observations have been made by Kayser (1977) regarding the influence of zinc on multi-species cultures and by Thomas and Seibert (1977) on the influence of copper on centric diatoms. This also can explain the broad range of $\mathrm{Cd}$ concentrations per chlorophyll $a$ at which accumulation and activity changed during investigation in Kiel Fjord. 
Consequently, it will be difficult to judge the degree of pollution in different water samples. Since the metal content in the cells is responsible for possible effects on organismic activity, it will remain difficult to decide from metal contents per unit chlorophyll a only whether metal concentrations in water had already affected phytoplankters because organisms may exhibit different tolerance levels at which damage manifests itself.

Acknowledgements. We thank the 'Bundesminister für Forschung und Technologie' for financial support and are grateful to Professor Dr. J. C. Duinker and Dr. B. Schneider for helpful discussions and for correcting an early version of our manuscript.

\section{LITERATURE CITED}

Bernhard, M., Zattera, A. (1969). A comparison between the uptake of radioactive and stable $\mathrm{Zn}$ by a marine unicellular algae. In: Nelson, G., Evans, D. (ed.) Proceedings of 2nd National Symposium on Radioecology, Washington, p. 389-398

Branica, M. (1970). Determination of zinc in the marine environment. IAEA Rep. No. 118

Canterford, G. S., Buchanan, A. S., Ducker, S. C. (1978). Accumulation of heavy metals by the marine Dithylum brightwellii (West) Grunow. Aust. J. Freshwat. Res. 29: 613-622

Canterford, G. S., Canterford, D. R. (1980). Toxicity of heavy metals to the marine diatom Dithylum brightwellii (West) Grunow: correlation between toxicity and metal speciation. J. mar. biol. Ass. U.K. 60: 227-242

Davies, A. G. (1978). Pollution studies with marine plankton. Part II Heavy metals. Adv. mar. Biol. 15: 381-478

Davies, A. G., Sleep, J. A. (1979). Inhibition of carbon fixation as a function of zinc uptake in natural phytoplankton assemblages. J. mar. biol. Ass. U.K. 59: 937-949
Davies, A. G., Sleep, J. A. (1980). Copper inhibition of carbon fixation in coastal phytoplankton assemblages. J. mar. biol. Ass. U.K. 60: 841-850

Duinker, J. C., Kramer, C. J. M. (1977). An experimental study on the speciation of dissolved zinc, cadmium, lead and copper in river Rhine and North Sea water, by differential pulsed anodic stripping voltametry. Mar. Chem. 5: $207-228$

Fisher, N. S., Frood, D. (1980). Heavy metals and marine diatoms: influence of dissolved organic compound on toxicity and selection for metal tolerance among four species. Mar. Biol. 59: 85-93

Kayser, H. (1977). Effects of zinc sulphate on the growth of mono- and multi-species cultures of some marine plankton algae. Helgoländer wiss. Meeresunters. 30: 682-696

Kayser, H., Sperling, K.-R. (1980). Cadmium effects and accumulation in cultures of Prorocentrum micans (Dinophyta). Helgoländer Meeresunters. 33: 89-102

Kremling, K., Petersen, H. (1981). The distribution of zinc, cadmium, copper, manganese and iron in waters of the open Mediterranean Sea. 'Meteor' Forschungsergebn. 23: 5-14

Rabsch, U., Elbrächter, M. (1980). Cadmium and zinc uptake, growth, and primary production in Coscinodiscus granii cultures containing low levels of cells and dissolved organic carbon. Helgoländer Meeresunters. 33: 79-88

Rabsch, U., Wolter, K., Krischker, P. (1984). Influence of low cadmium and zinc concentrations on batch culture Prorocentrum micans (Dinophyta) containing low levels of dissolved organic carbon. Mar. Ecol. Prog. Ser. 14: 275-285

Rai, L. C., Gaur, J. P., Kumar, H. D. (1981). Phycology and heavy-metal pollution. Biol. Rev. 56: 99-151

Smetacek, V. (1975). Die Sukzession des Phytoplanktons in der westlichen Kieler Bucht. Dissertation, Universität Kiel

Thomas, W H., Seibert, D. C. R. (1977). Effects of copper on the dominance and the diversity of algae: controlled ecosystem pollution experiments. Bull. mar. Sci. 27: 23-33

UNESCO (1966). Determination of photosynthetic pigments in sea water. Monographs on Oceanographic Methodology, UNESCO, Paris 